\title{
O Uso da Cartografia Social e das técnicas participativas no ordenamento territorial em projetos de Reforma Agrária
}

\author{
Social Cartography and participatory techniques's use in territorial planning in agrarian \\ reform projects
}

\author{
Cleiton Silva Ferreira Milagres \\ Universidade Federal de Viçosa - Mestrado em Extensão Rural
}

$\begin{array}{ll}\text { Orientador: } & \text { Prof. Dr. José Ambrósio Ferreira Neto } \\ \text { Membro da Banca: } & \text { Prof }^{\text {a }} \text {. Dr }{ }^{\text {a }} \text {. Sheila Maria Doula } \\ & \text { Prof. Dr. Marcelo Leles Romarco de Oliveira }\end{array}$

\section{RESUMO}

A formação dos assentamentos rurais é o resultado de uma ampla luta social pela posse da terra, envolvendo trabalhadores em inúmeros conflitos, gerando uma nova organização social, econômica e política. Na dinâmica de criação dos projetos de assentamento ocorre um novo processo de organização territorial no espaço geográfico habitado pela comunidade assentada. Sendo assim, para que se atenda, de forma apropriada, o planejamento territorial desejado pelas famílias assentadas, é necessário o desenvolvimento de técnicas que envolvam a comunidade na tomada de decisões acerca do uso da terra nesse espaço. Essa dissertação desenvolveu uma metodologia que insere os princípios da Cartografia Social nas técnicas do Diagnóstico Rural Participativo (DRP), tendo como base empírica os agricultores do Projeto de Assentamento Itatiaia, localizado no município de João Pinheiro no estado de Minas Gerais. Os principais resultados obtidos com o desenvolvimento da metodologia apontam que o envolvimento comunitário na construção coletiva de mapas georreferenciados visando o uso do solo e ocupação espacial dos lotes, possibilitou a incorporação e a tradução do saber local para um saber científico. Além disso, a técnica demonstrou que trabalhos que contemplem processos participativos envolvem também a confiança mútua em torno dos acordos negociados coletivamente, seja entre membros da comunidade seja entre esta e os técnicos que nela estavam. Foi percebido durante a realização do estudo que os assentados participantes do desenvolvimento da técnica buscam, com o exercício de mapear, representar os componentes da paisagem mais presentes no cotidiano das famílias assentadas. Outro ponto interessante observado no trabalho de campo foi que o sentimento de pertencimento e a identidade com o local se fizeram presentes na representação dos mapas elaborados pela comunidade e pelos depoimentos obtidos por eles durante as caminhadas ao longo do assentamento. Considerou-se, por fim, que quando a tecnologia é dominada apenas pelo técnico responsável pela elaboração dos mapas de planejamento territorial, a comunidade não se vê como parte da representação, sentindose marginalizada quanto ao acesso à informação que gerou a própria imagem. Por meio dos princípios de mapeamento participativo propostos pelo DRP e da inserção da cartografia social como método para a elaboração dos mapas, observou-se que é possível aos participantes elaborar um mapa participativo georreferenciado sobre o uso do solo e ocupação espacial dos lotes em projetos de reforma agrária.

Palavras-chave: cartografia social, técnicas participativas, reforma agrária. 


\begin{abstract}
A broad social struggle for land results in the formation of rural settlements. This kind of conflicts creates a new social, economics and politics organization. A new process of territorial organization occurs in the dynamic creation of settlement projects in the geographic space occupied by the settled community. So, to understand, appropriately, the desired territorial planning by the settled families, it is necessary to develop techniques that involve the community in taking decisions about the use of the land in this space. Thus, this research aimed to develop a methodology that puts the principles of Social Cartography in the techniques of Participatory Rural Appraisal (PRA), having as empirical bases farmers in Itatiaia Settlement Project, located in the city of João Pinheiro on Minas Gerais. The main results suggest that the community involvement in the collective construction of geo-referenced maps allow the incorporation and the translation of local knowledge to scientific knowledge. In addition, the technique showed that works including participatory processes involve mutual trust around agreements collectively negotiated. This mutual trust could be seen between members of the community and between these and the technicians. It was noted that during the research, settlers seek, with the exercise of mapping, represent the components of the landscape more present in daily life of settlers. Another interesting point observed in the representation of maps and in the statements obtained during the walking was the feeling of belonging and identity with the local. Finally, when technology is dominated only by the technician responsible for the preparation of maps of territorial planning, the community does not see himself as part of the representation, feeling marginalized on access to information that generated the own image. It could be concluded that use of the principles of participatory mapping proposed by DRP and of social cartography as a method for the preparation of maps allow participants develop a georeferenced participatory map about the use of land and the occupation of lots in agrarian reform projects.
\end{abstract}

Key-words: Social Cartography, participatory techniques's, agrarian reform 